\section{Vulnerability in the context of HIV and syphilis infection in a population of men who have sex with men (MSM) in Salvador, Bahia State, Brazil}

\author{
Vulnerabilidade no contexto da infecção por \\ HIV e sífilis numa população de homens que \\ fazem sexo com homens (HSH) no Município \\ de Salvador, Bahia, Brasil
}

Sandra Brignol 1

Inês Dourado 1

Leila D. Amorim 2

Lígia Regina Franco Sansigolo Kerr 3

\footnotetext{
${ }^{1}$ Instituto de Saúde Coletiva, Universidade Federal da Bahia, Salvador, Brasil. 2 Instituto de Matemática, Universidade Federal da Bahia, Salvador, Brasil. 3 Departamento de Saúde Comunitária, Universidade Federal da Ceará, Fortaleza Brasil.

Correspondence S. Brignol

Rua Treze, lote 22, quadra 99 Niterói, RJ 24340-235, Brasil. sandrabrignol@gmail.com
}

\begin{abstract}
Social, individual, and programmatic vulnerability of men who have sex with men (MSM) in the context of the HIV epidemic and other sexu ally transmitted infections (STI) is a reality in many countries. The survey Behavior, Attitudes, Practices, and Prevalence of HIV and Syphilis in Men Who Have Sex with Men in 10 Brazilian Cities selected 383 MSM in the city of Salvador, Bahia State, Brazil, using the respondent driven sampling (RDS) technique. Individual vulnerability: early sexual initiation (51\%), average of eight sex partners, and unprotected receptive anal sex with casual (32\%) and steady partners (45\%) and positive rapid tests HIV (6.5\%) and syphilis (9\%). Social vulnerability: young adults (80\%), black race/skin color (91\%), mean monthly family income of BRL 1,000.00, and personal history of discrimination (57\%). Programmatic factors: no previous HIV test (63\%) and no access to lubricant gel (88\%). The study showed a profile of vulnerability and the urgent need for interventions and STI prevention in the MSM population in Salvador, in addition to high prevalence rates for HIV and syphilis.
\end{abstract}

Male Homosexuality; HIV; Syphilis; Health Vulnerability

\section{Resumo}

A vulnerabilidade social, individual e programática dos homens que fazem sexo com homens (HSH), no contexto da epidemia do HIV e doenças sexualmente transmissíveis (DST) é uma realidade em muitos países. A pesquisa Comportamento, Atitudes, Práticas e Prevalência de HIV e Sífilis entre Homens que Fazem Sexo com Homens em 10 Cidades Brasileiras, selecionou, no Município de Salvador, Bahia, Brasil, 383 HSH via técnica respondent driven sampling (RDS). Vulnerabilidade individual: início precoce da vida sexual (51\%), média de oito parceiros sexuais, sexo anal receptivo desprotegido com parceiro casual (32\%) e fixo (45\%), e teste rápido positivo: HIV (6,5\%) e sífilis (9\%). Vulnerabilidade social: adultos jovens (80\%), negros (91\%), renda familiar média de $R \$ 1.000,00$ e sofreram algum tipo de discriminação (57\%). Fatores programáticos: sem teste do HIV (63\%), sem acesso ao gel lubrificante (88\%). Observou-se um perfil de vulnerabilidade e urgente necessidade de ações de intervenção e prevenção às DST no município na população pesquisada, além de altas prevalências do HIV e sífilis.

Homossexualidade Masculina; HIV; Sífilis; Vulnerabilidade em Saúde 


\section{Introduction}

HIV infections in the population of men who have sex with men (MSM) in many countries, has higher rates in comparison with other vulnerable populations, as evidenced in recent research 1. High HIV prevalence rates in MSM have been reported in the Caribbean (25.4\%), Sub-Saharan Africa (17.9\%), North America (15.4\%), and South and Southeast of Asia (14.7\%) 1 . In Latin America, the highest prevalence rates are in Argentina ( $9 \%$ to $51 \%$ ), Peru ( $10 \%$ to $22 \%$ ), Uruguay (22\%), Bolivia (21\%), Colombia (20\%), Mexico (15\%), and Paraguay (13\%) 2. In Brazil, recently estimated HIV prevalence rates in MSM ranged from $5.2 \%$ to $23.7 \%$, with an average of $14.2 \%$ in ten cities 3 , contrasting with the rate in the general population, where estimated prevalence in the $13-49$-year age group is $0.6 \% 4$. Syphilis also shows high prevalence among MSM, and this sexually transmitted infection (STI) is an important biological factor associated with HIV infection 1,2. Recent studies and literature reviews point to growing prevalence of syphilis in the MSM population $5,6,7,8,9$, exceeding $30 \%$ in some countries of Latin America 2,6,7,8 and Asia 9, confirming a previously reported trend 2 . In Brazil, a $14 \%$ lifetime history of syphilis among MSM was recently estimated by the survey Behavior, Attitudes, Practices, and Prevalence of HIV and Syphilis in Men Who Have Sex with Men in 10 Brazilian Cities.

As a public health concept, "vulnerability" refers to a set of factors that are structured in three dimensions (individual, social, and programmatic) and has been used to describe susceptibilities of population groups to important health problems 10 . However, in the context of the HIV/AIDS epidemic, the concept bears a close relationship to human rights, having appeared in the literature since the 1990s ${ }^{11}$. Individual and group vulnerability to HIV/AIDS partly reflects the stigma, prejudice, criminalization, and disrespect for human rights 12,13 , which in many countries hinder progress with policies for prevention and timely access to health services for diagnosis and treatment of HIV and other STI 12,13,14. In MSM, this reality has been confirmed by various international and national agencies and institutions 4,12,13.

The scenario of HIV infection and other STI among MSM can be assessed from an expanded perspective of factors. That is, the various dimensions of vulnerabilities (social, individual, and programmatic) $10,11,14$ converge in sociocultural and political-institutional aspects, individual characteristics, experiences, interactions, subjectivities, and personal histories 15 , as well as the characteristics of the social networks to which these individuals belong 1,16 .
From this perspective, the current study aims to analyze factors in the individual, social, and programmatic vulnerability of MSM in Salvador, Bahia State, Brazil, in the context of HIV/ AIDS. In Bahia State and in the city of Salvador, few studies have focused on HIV infection in the MSM population, and little is known about the socio-demographic profile of these men, their susceptibilities, sexual behavior, etc. In addition, local information is important in the context of the HIV epidemic to describe and present specificities that are unnoticed or diluted in more general analyses.

\section{Methodology}

This study used data collected in the city of Salvador, capital of Bahia State, as part of the multicenter survey entitled Behavior, Attitudes, Practices, and Prevalence of HIV and Syphilis among Men Who Have Sex with Men in 10 Brazilian Cities, which was also conducted in Manaus (Amazonas), Recife (Pernambuco), Campo Grande (Mato Grosso do Sul), Brasília (Federal District), Curitiba (Paraná), Itajaí (Santa Catarina), Santos (São Paulo), Belo Horizonte (Minas Gerais), and Rio de Janeiro. The study adopted a cross-sectional design in MSM living in these cities ${ }^{3}$. The results presented here are part of the $\mathrm{PhD}$ thesis 16 by the article's author and focus on analyses of the vulnerability concept 11 .

The data were collected in Salvador from October 2008 to October 2009. Participants were selected using respondent driven sampling (RDS) 17 . This recruitment technique is an option for selecting individuals from hard-to-reach populations like MSM 18,19.

The study's first phase consisted of four focus groups with MSM with different socio-demographic characteristics and sexual identities 3,16. After identifying the MSM that had wide social networks and that were willing to collaborate with the study, they were invited to be "seeds" in the study, that is, to begin recruiting other participants. The seeds received numbered coupons with an expiration date to distribute to MSM in their social networks, allowing to control MSM participation and connect each "recruitee" to his "recruit" (Figures 1 and 2).

The planned sample of 350 MSM in Salvador 3 was expanded to 394 participants. Three hundred and eighty-three MSM (97\%) met the study's inclusion criteria: age 18 years or older, at least one sexual encounter with another man during the year prior to the interview, a broad social network with other MSM, and residence in Salvador 3. 


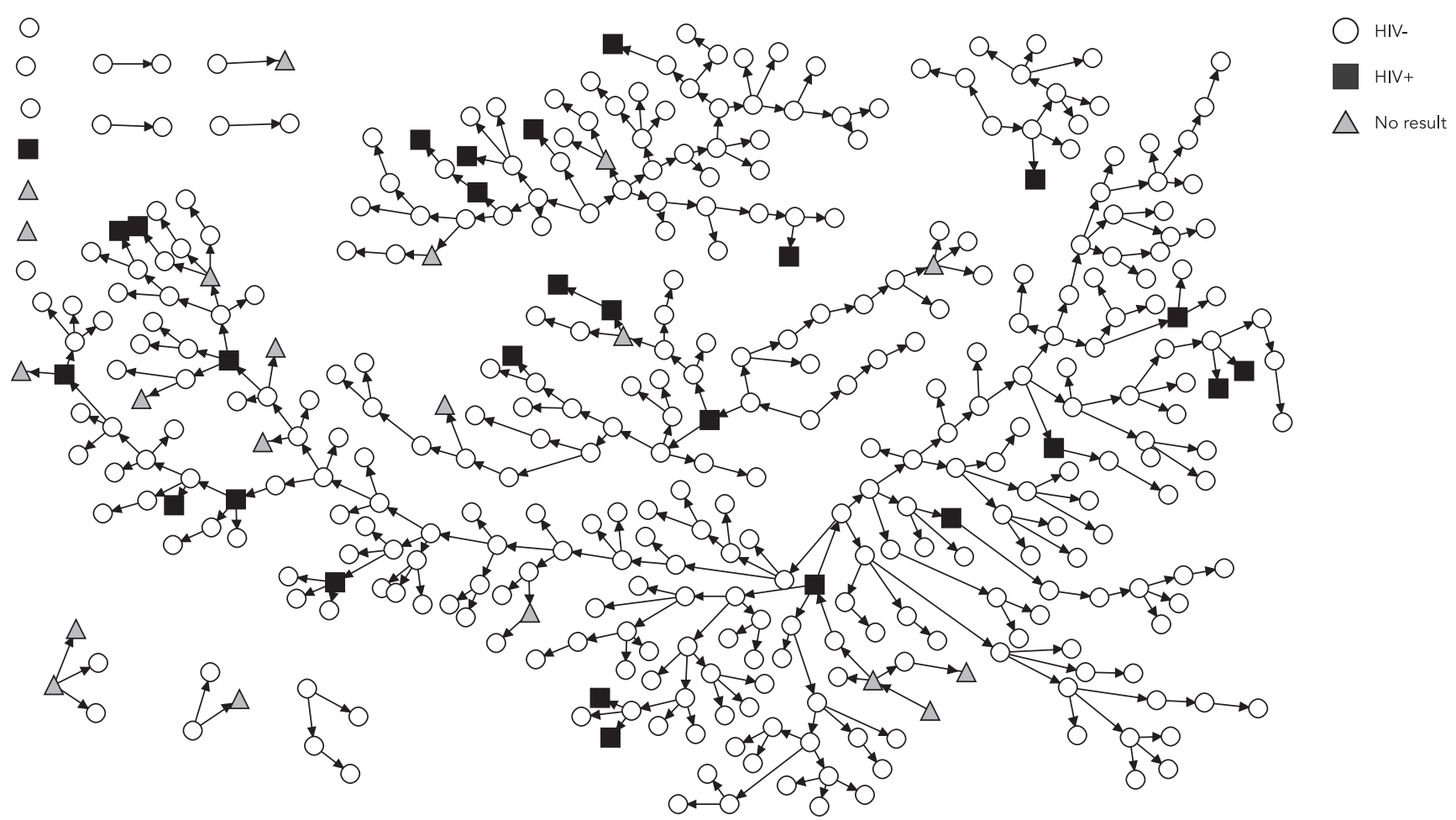

The number of friends/acquaintances within the social network (degree) and the measure of "homophily" 17 (degree of similarity between recruiter and recruit in relation to HIV and syphilis) were used to calculate the "individual RDS sampling weights" for adjusting the parameter's estimation procedure 17 . These weights were calculated with the Respondent Driven Sampling Analysis Tool 6.0.1 (RDSAT; http://www.respon dentdrivingsampling.org).

The "seeds" were included in the analyses to reduce the loss of sampling units. To fill in the missing data for "degree", we used the mean of the number of friends/acquaintances within the social network (28 individuals), using simple imputation since the rate of missing data was less than $5 \%$ for degree.

In Salvador, 1,149 coupons were distributed, of which 375 were used. The vast majority of the recruiters and their recruits (284) received meal tickets worth BRL 5 and BRL 10 for a snack since the waiting time for completing all the stages in their participation (reception, interview, coun- seling, and rapid pre and post-tests) could exceed three hours.

To meet all the other objectives 16 , a questionnaire with 27 questions was used (only in the city of Salvador). However, the current article only used data comprising the following variable: "Have you used or do you usually use health services in the Brazilian Unified National Health System (SUS)?" Identification of HIV infection and detection of antibodies to Treponema pallidum used the rapid tests Rapid Check HIV-1\&2 (Núcleo de Doenças Infecciosas, Universidade Federal do Espírito Santo, Vitória, Brazil) Bio-Manguinhos HIV-1\&2 (Instituto de Tecnologia em Imunobiológicos, Fundação Oswaldo Cruz, Rio de Janeiro, Brazil) e SD Bioline Syphilis 3.0 (Standard Diagnostics Inc., Yongin, South Korea), respectively. All the procedures for these tests followed Brazilian Ministry of Health guidelines and recommendations (Rulings n. 34 of October 28, 2005, and n. 3.242 of December 30, 2011, and complementary guidelines) 3 . 
Figure 2

Distribution of the recruitment of men who have sex with men (MSM) in Salvador, Bahia State, Brazil, 2008-2009, according to the result of the rapid test for syphilis.

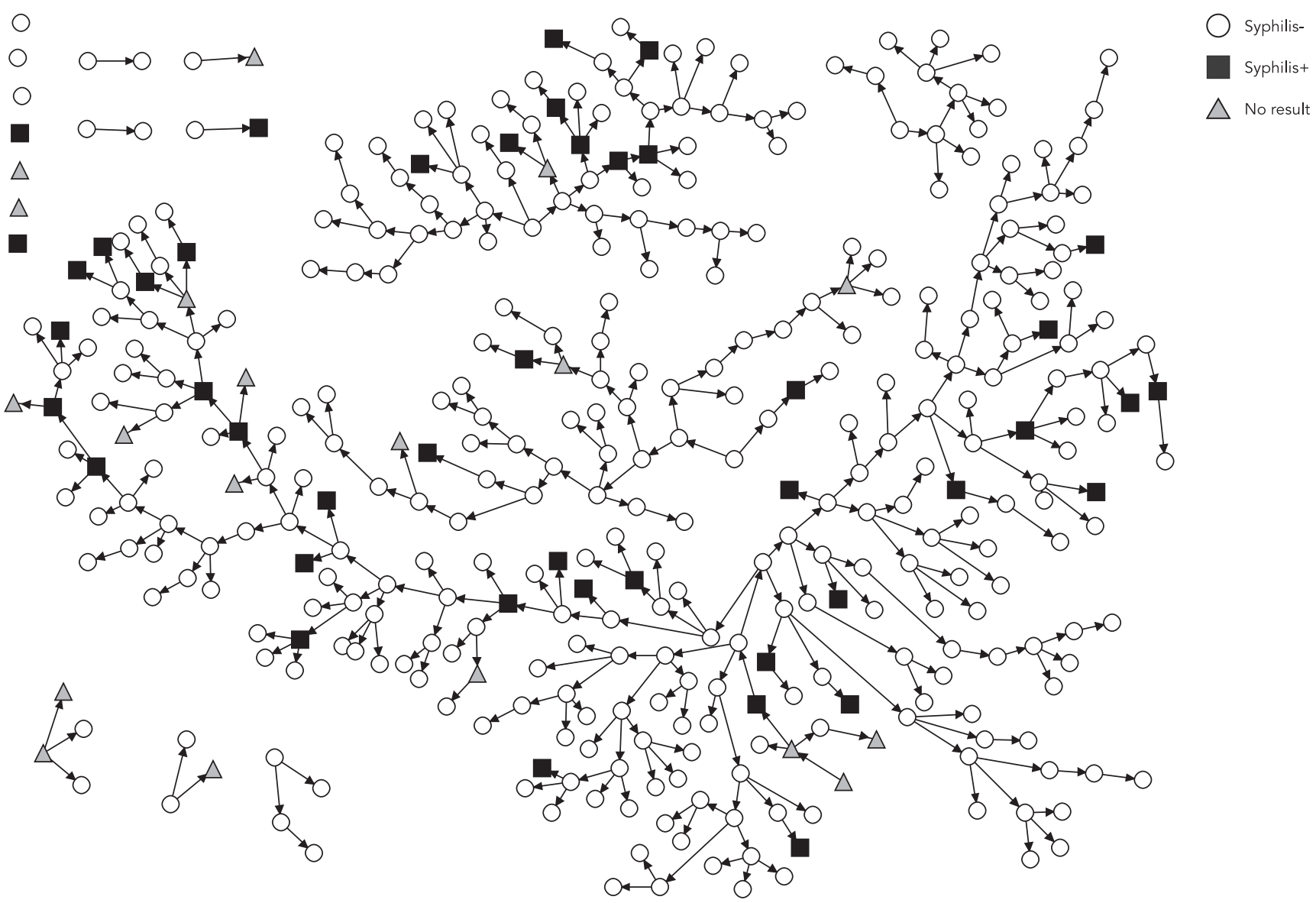

The study's variables were grouped according to the following dimensions of vulnerability 10,11: (1) individual: results of the rapid tests for HIV and syphilis, self-reported STI symptoms (penile or anal sores, blisters, warts, or discharge), age on the date of the interview, total number of sex partners (men, women, and transvestites) in the six months prior to the interview, unprotected receptive anal sex with the last steady partner and with the last casual partner, and age at sexual initiation; (2) social: schooling, race/skin color, monthly family income, current work status, sexual category, history of some type of discrimination (by race/skin color, social status, age, or sexual orientation), having been cursed (sometime in life and during the previous year), and if the individual had told his parents that he was sexually attracted to men; and (3) programmatic: results of the rapid tests for HIV and syphilis, report of previous HIV test, report of previous test for syphilis, knowledge of some health service with free HIV testing, access to some information or input for STI prevention in the previous 12 months, having received lubricant gel in the previous 12 months, participation in (or knowledge of) some activity organized by a church, religious group, HIV/AIDS or human rights nongovernmental organization (NGO), or reported previous or customary use of some health service in the SUS 16.

New variables were created, based on the aggregation or combination of categories or questions from the multicenter survey's instrument. Categorizations were based on recommenda- 
tions from the literature and in order for the proportions to reach at least $5 \%$ of the total sample (so as not to comprise hypotheses testing). The new variables were: "total number of sex partners", "receptive anal sex with last male casual partner", "receptive anal sex with last male steady partner", "report of some type of discrimination in the previous year", "having told parents about his sexual attraction to men", "access to some information or material for STI prevention", and "participation in or knowledge of some activity organized by a church, religious group, HIV/AIDS or human rights NGO" 16 .

Analyses of the associations between vulnerability factors and the results of HIV and syphilis tests used Fisher's exact test with significance level at $5 \%$. The study protocol complied with the ethical guidelines of Resolution n. 196/96 of the Brazilian National Health Council for research involving human subjects and was approved by the Ethics Research Committee (CONEP) of the Brazilian Ministry of Health (protocol n. 14.494) and the Institutional Review Board of the Bahia State Health Department (SESAB) (protocol n. 241/2008).

\section{Results}

Participants were recruited by 18 "seeds", of which four produced recruitment chains (Figure 1). The smallest chain had 12 participants, followed by two intermediate chains (48 and 58 participants) and the largest chain, consisting of 235 MSM. Of the invitations that were distributed, $32.6 \%$ were retrieved, and $77.6 \%$ of the meal tickets were redeemed by participants.

Sixty-nine percent of MSM reported participating in the study because they wanted to have an HIV test, and $94 \%$ of the participants agreed to conduct the rapid tests for HIV and syphilis. The main reason for refusing to take the test was having been tested recently.

The heterogeneity of recruitment, considering the result of the rapid HIV test, was shown by the homophily coefficient. The group of seropositive MSM showed a coefficient of -0.274 and the seronegative group 0.011 , both close to zero, indicating absence of recruitment bias according to HIV infection and syphilis. Figures 1 and 2 show the absence of a recruitment pattern.

According to individual vulnerability factors (Table 1 ), $80 \%$ of the participants were 18 to 29 years of age, with a mean age of 25.3 years $(\mathrm{SD}=$ 6.5 years), and $51 \%$ reported sexual initiation before they were 15 years old. Prevalence of HIV infection was $6.5 \%$ (95\%CI: 3.9; 9.0). The rapid test for syphilis was positive in $8.8 \%$ (95\%CI: $5.7 ; 11.7$ ).
Twenty-four percent of the MSM reported STI symptoms in the previous 12 months; of these, $15 \%$ had not gone for treatment. Mean number of sex partners was eight in the six months prior to the interview. During this same period, $32 \%$ reported unprotected receptive anal sex with the last male casual partner (95\%CI: 25.8; 37.7) and $45 \%$ with the last male steady partner $(95 \% \mathrm{CI}$ : 37.6; 52.1).

As shown in Table 2, for the socioeconomic and demographic variables comprising the social vulnerability of MSM, the majority of the interviewees were black or brown (African-descendants) (91.4\%; 95\%CI: 88.5; 94.3); 33\% (95\%CI: 27.7 ; 37.4 ) had eight years of schooling or less. Monthly family income greater than BRL 600.00 (USD 300.00) was reported by $67 \%$ (95\%CI: 61.4 ; 73.0) of the participants. Thirty-eight percent of the MSM $(95 \% \mathrm{CI}: 32.7 ; 42.7)$ reported that they were currently unemployed. Of the unemployed, $59 \%$ reported that they were looking for work but could not find any, and $71 \%$ said they were the heads of their households. Fifty-seven percent (95\%CI: 51.6; 61.8) had experienced some type of discrimination in the year prior to the interview. $43.5 \%$ reported not having told their parents about their sexual attraction to other men (95\%CI: 38.2; 48.8).

As for programmatic vulnerability (Table 2), 63\% (95\%CI: 57.8; 67.9) reported not having been tested for HIV, and 20\% (95\%CI: 16.0; 24.3) had not had a syphilis test ever in life. In the year prior to participating in the study, $45 \%$ (95\%CI: 39.7 ; 50.2) had not used health services in the SUS, $79 \%$ had accessed some type of material for STI prevention, $12 \%$ had received lubricant gel, and $41 \%$ reported participation in or knowledge of some activity organized by a church, religious group, HIV/AIDS or human rights NGO.

Vulnerability factors like the rapid syphilis test, current age, age at sexual initiation, total number of sex partners in the previous six months, prior syphilis test, and having received lubricant gel in the previous year were associated with HIV infection. The factors sexual category, result of the HIV test, current age, age at sexual initiation, HIV test sometime in life, knowledge of where and how to have a free HIV test, prior syphilis test, having received educational material or information on STI, and participation in some organized activity were associated with lifetime history of syphilis (Table 3 ).

\section{Discussion}

The analysis of factors from the dimensions of vulnerability allowed portraying the social con- 
Table 1

Descriptive analysis of individual vulnerability in a sample of men who have sex with men (MSM) in Salvador, Bahia State, Brazil, $2008-2009$.

\begin{tabular}{|c|c|c|c|c|c|}
\hline \multirow[t]{2}{*}{ Individual vulnerability factors } & \multicolumn{3}{|c|}{ RDS-weighted } & \multicolumn{2}{|c|}{ RDS-non-weighted } \\
\hline & $\mathrm{n}$ & $\%$ & $95 \% \mathrm{Cl}$ & $\%$ & $95 \% \mathrm{Cl}$ \\
\hline \multicolumn{6}{|l|}{ Result of HIV test in the study } \\
\hline Negative & 340 & 93.5 & & 92.6 & \\
\hline Positive & 23 & 6.5 & $3.9 ; 9.0$ & 7.4 & $4.9 ; 10.6$ \\
\hline \multicolumn{6}{|l|}{ Result of rapid test for syphilis in the study } \\
\hline Negative & 331 & 91.2 & & 87.9 & \\
\hline Positive & 32 & 8.8 & $5.7 ; 11.7$ & 12.1 & $8.9 ; 15.9$ \\
\hline \multicolumn{6}{|l|}{ Reported STI symptoms * } \\
\hline Yes & 89 & 24.5 & & 23.8 & \\
\hline No & 274 & 75.5 & $71.1 ; 80.0$ & 76.2 & $71.7 ; 80.4$ \\
\hline \multicolumn{6}{|l|}{ Age on date of interview (years) } \\
\hline $30-53$ & 71 & 19.7 & & 24.1 & \\
\hline $18-29$ & 291 & 80.3 & $76.2 ; 84.4$ & 75.9 & $71.2 ; 80.1$ \\
\hline \multicolumn{6}{|l|}{ How old were you the first time you had sex? (years) } \\
\hline$\geq 15$ & 179 & 49.2 & & 52.5 & \\
\hline$<15$ & 184 & 50.8 & $45.6 ; 55.9$ & 47.5 & $42.4 ; 52.7$ \\
\hline \multicolumn{6}{|l|}{ During the six months prior to the interview } \\
\hline \multicolumn{6}{|c|}{ Total number of sex partners (men, women, and transvestites) } \\
\hline$<8$ & 291 & 85.7 & & 79.8 & \\
\hline$\geq 8$ & 49 & 14.3 & $10.6 ; 18.1$ & 20.2 & $16.2 ; 24.7$ \\
\hline \multicolumn{6}{|c|}{ Unprotected receptive anal sex ${ }^{\star \star}$ with last male casual partner } \\
\hline Did not have anal sex or always used a condom & 139 & 68.3 & & 72.3 & \\
\hline Failed to use a condom at least once & 65 & 31.7 & $25.8 ; 37.7$ & 27.7 & $22.2 ; 33.6$ \\
\hline \multicolumn{6}{|c|}{ Unprotected receptive anal sex ${ }^{* \star}$ with last male steady partner } \\
\hline Did not have anal sex or always used a condom & 88 & 55.2 & & 51.3 & \\
\hline Failed to use a condom at least once & 71 & 44.9 & $37.6 ; 52.1$ & 48.7 & $41.6 ; 55.9$ \\
\hline
\end{tabular}

95\% Cl: 95\% confidence interval; RDS: respondent driven sampling; STI: sexually transmitted infection.

* Self-reported penile or anal sores, blisters, warts, or discharge;

** No use of male condom with last male sex partner.

text of MSM participating in the study, in addition to describing their individual characteristics (cognitive, biological, emotional, etc.), and access to education materials and activities for prevention of HIV infection and other STI.

In the analysis of individual vulnerability factors like the results of rapid tests for HIV and syphilis, the prevalence of these STI was high among MSM recruited in this study, but below the mean value for the ten Brazilian cities 3 (HIV: $14.2 \%$; syphilis: $14 \%$ ). Meanwhile, these estimates are high compared to the prevalence rates in the overall male population in Brazil (HIV: $0.8 \%$; syphilis: $1.3 \%$ ) 4,20 , male industrial workers (HIV: $1.7 \%$; syphilis: $1.9 \%$ ) 21 , military conscripts (HIV: $0.1 \%$; syphilis: $0.5 \%$ ) 22, and in the Bela Vista Project with MSM (HIV: 2.1\%; syphilis: 13.5\%) 23. Recent studies that also used the RDS methodol- ogy among MSM in different countries showed HIV infection prevalence rates greater than $10 \%$ $6,24,25,26$, and some studies have shown prevalence rates greater than $30 \% 27,28,29$.

As for syphilis, the prevalence found in Salvador is close to that reported in the international literature 2,5,7,8,9, including RDS studies with MSM 6,30, and shows the high prevalence of syphilis among MSM interviewed.

The factors analyzed here that were associated with prevalence rates for HIV, syphilis, and STI as a whole in the MSM population in different countries show that not only biological factors but also social life, mental health, affective experiences, discrimination and other subjective aspects (such as perceptions and expectations, among others) can lead to increased exposure to these infections. Thus, prevention and interven- 
Table 2

Descriptive analysis of social and programmatic vulnerability in Salvador, Bahia State, Brazil, 2008-2009.

\begin{tabular}{|c|c|c|c|c|c|}
\hline \multirow[t]{2}{*}{ Vulnerability factors } & \multicolumn{3}{|c|}{ RDS-weighted } & \multicolumn{2}{|c|}{ RDS-non-weighted } \\
\hline & $\mathrm{n}$ & $\%$ & $95 \% \mathrm{Cl}$ & $\%$ & $95 \% \mathrm{Cl}$ \\
\hline \multicolumn{6}{|l|}{ Social vulnerability } \\
\hline \multicolumn{6}{|l|}{ Schooling (years) } \\
\hline$>8$ & 258 & 67.4 & & 82.2 & \\
\hline$\leq 8$ & 125 & 32.5 & $27.7 ; 37.4$ & 17.8 & $14.1 ; 22.0$ \\
\hline \multicolumn{6}{|l|}{ Race/Color } \\
\hline White/Other & 31 & 8.6 & & 11.7 & \\
\hline African-descendant (brown and black) & 332 & 91.4 & $88.5 ; 94.3$ & 88.3 & $84.6 ; 91.3$ \\
\hline \multicolumn{6}{|l|}{ Monthly family income (BRL) } \\
\hline$\leq 600.00$ & 84 & 32.8 & & 26.6 & \\
\hline$>600.00$ & 173 & 67.2 & $61.4 ; 73.0$ & 73.4 & $67.8 ; 78.6$ \\
\hline \multicolumn{6}{|l|}{ Current work status } \\
\hline Employed & 226 & 62.3 & & 67.5 & \\
\hline Unemployed & 136 & 37.7 & $32.7 ; 42.7$ & 32.5 & $27.9 ; 37.5$ \\
\hline \multicolumn{6}{|l|}{ Sexual category } \\
\hline Homosexual/Gay & 183 & 50.6 & & 63.0 & \\
\hline MSM & 179 & 49.4 & $44.3 ; 54.6$ & 37.0 & $32.1 ; 42.1$ \\
\hline \multicolumn{6}{|c|}{$\begin{array}{l}\text { Suffered some type of discrimination (race/color, social status, age, sexual } \\
\text { orientation, or cursing) in life and in the last year }\end{array}$} \\
\hline No & 157 & 43.2 & & 34.2 & \\
\hline Yes & 206 & 56.7 & $51.6 ; 61.8$ & 65.8 & $60.8 ; 70.5$ \\
\hline \multicolumn{6}{|c|}{ Have you told your parents that you feel sexually attracted to men? } \\
\hline Yes & 183 & 56.5 & & 43.7 & \\
\hline No & 140 & 43.5 & $38.2 ; 48.8$ & 56.3 & $51.0 ; 61.5$ \\
\hline \multicolumn{6}{|l|}{ Programmatic vulnerability } \\
\hline \multicolumn{6}{|l|}{ Previous HIV test? } \\
\hline Yes & 135 & 37.2 & & 44.1 & \\
\hline No & 228 & 62.8 & $57.8 ; 67.9$ & 55.9 & $50.7 ; 60.9$ \\
\hline \multicolumn{6}{|c|}{ Do you know of some health service that provides free HIV testing? } \\
\hline Yes & 121 & 33.4 & & 43.9 & \\
\hline No & 242 & 66.6 & $61.7 ; 71.4$ & 56.1 & $51.0 ; 61.2$ \\
\hline \multicolumn{6}{|l|}{ Previous test for syphilis? } \\
\hline Yes & 282 & 79.9 & & 73.3 & \\
\hline No & 71 & 20.1 & $16.0 ; 24.3$ & 26.7 & $22.2 ; 31.2$ \\
\hline \multicolumn{6}{|c|}{ Have you used or do you usually use public healthcare services (SUS)? } \\
\hline Yes & 189 & 55.1 & & 59.0 & \\
\hline No & 155 & 44.9 & $39.7 ; 50.2$ & 41.0 & $36.0 ; 46.2$ \\
\hline \multicolumn{6}{|c|}{ Have you accessed some information or input for STI prevention? * } \\
\hline Yes & 286 & 78.8 & & 82.2 & \\
\hline No & 77 & 21.2 & $17.0 ; 25.4$ & 17.8 & $14.1 ; 22.0$ \\
\hline \multicolumn{6}{|l|}{ Have you received lubricant gel? * } \\
\hline Yes & 44 & 12.1 & & 13.1 & \\
\hline No & 319 & 87.9 & $84.5 ; 91.3$ & 86.9 & $83.2 ; 90.2$ \\
\hline \multicolumn{6}{|c|}{$\begin{array}{l}\text { Have you participated in (or do you know of) some activity organized by a } \\
\text { church, religious group, or HIV-AIDS/human rights NGO? }\end{array}$} \\
\hline Yes & 149 & 41.1 & & 38.9 & \\
\hline No & 214 & 58.9 & $53.8 ; 64.0$ & 61.1 & $56.0 ; 66.0$ \\
\hline
\end{tabular}

95\% Cl: 95\% confidence interval; MSM: men who have sex with men; NGO: non-governmental organization; RDS: respondent driven sampling; STI: sexually transmitted infection; SUS: Brazilian Unified National Health System.

* Refers to the 12 months prior to participation in the study. 
Table 3

Prevalence of HIV and syphilis according to vulnerability factors in Salvador, Bahia State, Brazil, 2008-2009.

\begin{tabular}{|c|c|c|c|c|c|c|}
\hline \multirow[t]{2}{*}{ Vulnerability factors } & \multicolumn{3}{|c|}{ HIV+ } & \multicolumn{3}{|c|}{ Syphilis+ } \\
\hline & $n=27$ & $\%$ & p-value & $n=44$ & $\%$ & p-value \\
\hline \multicolumn{7}{|l|}{ Individual vulnerability } \\
\hline \multicolumn{7}{|l|}{ Result of HIV test in the study } \\
\hline Negative & - & - & & 34 & 10.1 & 0.000 \\
\hline Positive & - & - & & 10 & 37.0 & \\
\hline \multicolumn{7}{|l|}{ Result of rapid test for syphilis in the study } \\
\hline Negative & 17 & 5.3 & 0.000 & - & - & \\
\hline Positive & 10 & 22.7 & & - & - & \\
\hline \multicolumn{7}{|l|}{ Reported STI symptoms * } \\
\hline No & 17 & 6.2 & 0.158 & 31 & 11.2 & 0.355 \\
\hline Yes & 10 & 11.4 & & 13 & 14.8 & \\
\hline \multicolumn{7}{|l|}{ Age on date of interview (years) } \\
\hline $18-29$ & 16 & 5.8 & 0.033 & 24 & 8.6 & 0.002 \\
\hline $30-53$ & 11 & 13.1 & & 19 & 22.6 & \\
\hline \multicolumn{7}{|l|}{ How old were you the first time you had sex? (years) } \\
\hline$\geq 15$ & 8 & 4.3 & 0.026 & 12 & 6.4 & 0.001 \\
\hline$<15$ & 19 & 10.9 & & 32 & 18.2 & \\
\hline \multicolumn{7}{|c|}{ Total number of sex partners (men, women, and transvestites) } \\
\hline$<8$ & 14 & 5.1 & 0.008 & 30 & 10.9 & 0.219 \\
\hline$\geq 8$ & 11 & 15.5 & & 12 & 16.9 & \\
\hline \multicolumn{7}{|c|}{ Unprotected receptive anal sex with last male casual partner } \\
\hline Did not have anal sex or always used a condom & 14 & 8.1 & 1.000 & 25 & 14.4 & 0.687 \\
\hline Failed to use a condom at least once & 5 & 7.6 & & 11 & 16.7 & \\
\hline \multicolumn{7}{|c|}{ Unprotected receptive anal sex with last male steady partner } \\
\hline Did not have anal sex or always used a condom & 8 & 8.3 & 0.571 & 13 & 13.5 & 0.242 \\
\hline Failed to use a condom at least once & 5 & 5.6 & & 7 & 7.8 & \\
\hline \multicolumn{7}{|l|}{ Social vulnerability } \\
\hline \multicolumn{7}{|l|}{ Schooling (years) } \\
\hline$>8$ & 24 & 8.1 & 0.440 & 31 & 10.5 & 0.096 \\
\hline$\leq 8$ & 3 & 4.5 & & 12 & 17.9 & \\
\hline \multicolumn{7}{|l|}{ Monthly family income (BRL) } \\
\hline$\leq 600.00$ & 4 & 5.7 & 0.604 & 5 & 7.1 & 0.631 \\
\hline$>600.00$ & 15 & 8.1 & & 19 & 10.2 & \\
\hline \multicolumn{7}{|l|}{ Sexual category } \\
\hline MSM & 6 & 4.4 & 0.101 & 10 & 7.4 & 0.032 \\
\hline Homosexual/Gay & 21 & 9.3 & & 34 & 15.0 & \\
\hline \multicolumn{7}{|c|}{ Have you told your parents that you feel sexually attracted to men? } \\
\hline Yes & 7 & 4.6 & 0.045 & 12 & 8.0 & 0.015 \\
\hline No & 20 & 10.7 & & 32 & 17.0 & \\
\hline \multicolumn{7}{|l|}{ Programmatic vulnerability } \\
\hline \multicolumn{7}{|l|}{ Previous HIV test } \\
\hline Yes & 15 & 9.5 & 0.227 & 28 & 17.7 & 0.005 \\
\hline No & 12 & 5.9 & & 16 & 7.8 & \\
\hline \multicolumn{7}{|c|}{ Do you know of some health service that provides free HIV testing? } \\
\hline Yes & 15 & 9.6 & 0.226 & 29 & 18.5 & 0.002 \\
\hline No & 12 & 5.8 & & 15 & 7.3 & \\
\hline \multicolumn{7}{|l|}{ Previous test for syphilis } \\
\hline Yes & 14 & 5.4 & 0.012 & 24 & 9.2 & 0.009 \\
\hline No & 13 & 13.8 & & 19 & 20.2 & \\
\hline
\end{tabular}

(continues) 


\begin{tabular}{|c|c|c|c|c|c|c|}
\hline \multirow[t]{2}{*}{ Vulnerability factors } & \multicolumn{3}{|c|}{ HIV+ } & \multicolumn{3}{|c|}{ Syphilis+ } \\
\hline & $n=27$ & $\%$ & p-value & $n=44$ & $\%$ & p-value \\
\hline \multicolumn{7}{|c|}{ Programmatic vulnerability } \\
\hline \multicolumn{7}{|c|}{ Received lubricant gel in the last 12 months? } \\
\hline Yes & 8 & 16.0 & 0.021 & 10 & 20.0 & 0.098 \\
\hline No & 19 & 6.1 & & 34 & 10.8 & \\
\hline \multirow{2}{*}{\multicolumn{7}{|c|}{$\begin{array}{l}\text { Have you participated in (or do you know of) some activity organized } \\
\text { by a church, religious group, or HIV-AIDS/human rights NGO? }\end{array}$}} \\
\hline & & & & & & \\
\hline Yes & 9 & 6.3 & 0.545 & 12 & 8.3 & 0.073 \\
\hline No & 18 & 8.2 & & 32 & 14.6 & \\
\hline
\end{tabular}

MSM: men who have sex with men; NGO: non-governmental organization; STI: sexually transmitted infection.

* Self-reported penile or anal sores, blisters, warts, or discharge.

Note: statistical significance set at $5 \%$ by Fisher's exact test.

tions targeting MSM should be broad and comprehensive, including social policies aimed at reducing stigma and improving living conditions and access to health services.

Among the individual vulnerability factors associated with HIV infection and a positive rapid test for syphilis, MSM in this study had an average age of 25 years old, close to that of the MSM in the ten Brazilian cities study (27.5 years) ${ }^{3}$, but they were younger when compared to MSM in RDS studies in other countries, where the mean age ranged from 30 to 41 years $2,4,25,28,30,31$. This could be considered a recruitment bias in our study, but it might also reflect aspects of the male population in Salvador, with a high proportion in the 15 to 39-year age group according to the 2010 Population Census 32 .

Age at sexual initiation was also associated with these STI. Early initiation (before 15 years) in Salvador was much more common (50.8\%) than in the population from 15 to 64 years of age $(26.8 \%)$ and among men $(17 \%)$ in this same age group 33 , in populations of young Brazilians 34,35 , and even among young males 36 . This factor was not explored in the studies of MSM that we consulted, but other results show its importance and relationship to aspects of sexual activity and reproductive health in the young Brazilian population 33,35 since some researchers contend that behavior in the first sexual experiences can be maintained throughout the individuals' sex lives. Young age at sexual initiation is also a risk factor for HIV infection and other STI 35.

A factor related to the sexual practices of MSM and which was associated with HIV infection and other STI is the high number of partners, which can increase their exposure to HIV infection, especially with inconsistent condom use in receptive anal sex, which can occur due to alcohol use, psychoactive substances before and during sex, or as a result of stigma and discrimination 37,38 . Some RDS studies have found fewer sexual partners than in this study 24,28,39,40, but our findings are close to other results of RDS studies with MSM 6,25,27,30. Still, such differences may be due to the lack of a standardized period for which the number of partners was computed, varying widely in the literature, or to characteristics like the size of MSM social networks, age, schooling, and social class, factors that may be associated with the number of sexual partners in this sample.

Unprotected receptive anal sex was analyzed separately for the last casual partner and last steady partner. The latter was more common in this study when compared to patterns in other countries 1: two RDS studies showed lower percentages 25,41 than in Salvador. However, regarding casual partners, other RDS showed similar percentages to those found in this research 27,30, indicating high exposure of MSM in Salvador, since the probability of HIV infection can reach $40.4 \%$ per sexual partner in unprotected receptive anal sex 37.

Social vulnerability also plays a relevant role in the context of STI, since it can hinder access to education, work, health services, and other processes that protect against these infections. Sexual category was associated with the result of the syphilis test (prevalence of syphilis and HIV was higher among homosexuals). The literature generally reports an association between sexual identity and risky sexual practices for HIV infection $12,29,38,42$, stigma 29 , difficult access to health services 31,43 , and HIV infection 26,43 .

Another factor associated with positive HIV and syphilis tests was not disclosing one's sexual identity to parents. These results may indicate 
difficulty by MSM in assuming their sexuality in the family, which may reflect the prejudice and stigma in Bahian society. Salvador, like Brazil, still shows little tolerance for the LGBT population (lesbians, gays, bisexuals, and transsexuals) and is one of the Brazilian cities with the most violent crimes and homicides against this population 44,45 .

This study found a high percentage of exposure to some form of discrimination, whether on grounds of race/skin color, social condition, age, or sexual orientation. This reality has been identified in RDS studies with MSM in other countries 29,31 and is a serious factor associated with violence and barriers to health services. The literature also reports stigma and discrimination and their association with risky sexual practices for HIV infection and other STI, especially in stigmatized populations $12,14,38$.

Factors related to access to testing for HIV and syphilis, inputs, information, prevention and health services belong to the dimension of programmatic vulnerability. HIV testing is an important public health measure for prevention and early diagnosis of the infection.

The percentage of participants that reported a previous HIV test (37\%) was close to that of Brazil's general population (36.5\%) 33 and higher than the country's male population (27\%) 33 , but some $50 \%$ lower than in a population of black and Latino MSM in the United States 24,41, or among MSM with high-risk practices for HIV infection 28. It was also lower than the results presented in the last report of the Joint United Nations Programme on HIV/AIDS (UNAIDS) (42\%) 12 and in the Brazilian multicenter study (49\%) 3 and other populations of MSM 42. This is one of the most important indicators for monitoring the HIV epidemic, since it promotes a link between individuals and health services and can be one of the main entry points for healthcare via counseling and support for persons with HIV and other STI, allowing contact with information and preventive measures.

Reporting a previous syphilis test was statistically associated with HIV infection and syphilis, as in other studies 24,28 , but it can also be associated with risky sexual practices for STI 24,27,28,41.

This study found a high rate of previous testing for syphilis $(79.9 \%)$ when compared to previous testing for HIV (37.2\%), thus pointing to missed opportunities for HIV testing at the same visit for the syphilis test, contrary to Brazil's national policy for dealing with the HIV epidemic ${ }^{4}$. The literature agrees on the need to expand testing for HIV and other STI since it can reduce involvement in risky sexual practices for STI $12,24,25,28,29,31,41$.
In addition to testing for HIV and syphilis, the use of public healthcare services can decrease the programmatic vulnerability of MSM: when individuals are in touch to preventive activities and access to information on reducing the risk of HIV infection and STI. The MSM here showed a high use of health services (59\%), higher than the average for the male Brazilian population (9\%) 46 (other studies have shown that Brazilian men make less use of health services 47 , especially the population of men with homosexual practices 48 , as also occurs in other countries 12,29). Our results, however, were lower than in various studies in the United States 24,28 .

Lower access to lubricant gel was associated with a lifetime history of HIV infection and syphilis, and difficulty in access to lubricant gel has also been reported in other countries in the MSM population 38,42 . Lubricant gel is important for the prevention of HIV infection 12. Although its use has increased in recent years, access to the gel is still limited, posing a major challenge for the SUS, especially in groups that are more exposed to HIV 4,38.

The identification of individuals in difficultto-reach or "hidden" populations 18,19 , such as MSM in the context of the HIV epidemic, is still a huge challenge for epidemiological research. This is because same-sex affective or sexual relations are still seen with widespread social discrimination and even violence in Brazil 44,45 and in other countries 12,29. Studies using the RDS methodology are currently one option for reaching these populations, in which it is impossible to obtain a random sample $18,19,49$. RDS is relatively efficient for reaching social networks in difficultto-reach populations 49 , thus many researchers have used the technique to select individuals in these populations, classified as "hidden" 49.

Four recruitment chains were formed in Salvador, but to achieve this result the study used a high number of "seeds". Some initial recruiters did not continue recruiting, reflecting the difficulty in accessing the MSM population in this State capital, and this occurred mainly among MSM from higher social classes and more than 25 years of age. Another difficulty in recruiting was to convince men in the networks to seek a public healthcare service.

\section{Limitations}

The RDS methodology entails some limitations that have been widely discussed in the literature and include sample size calculation, dependency between sampling units, and definition of estimators 50. Although some analytical proposals 
are optimistic, the problems persist, limiting interpretation of the results, which cannot be generalized to the target populations as a whole 50 . In addition, in our study sample we identified a selection bias in favor of younger, black, lowincome men. The results from testing the hypotheses should be assessed with caution due to the dependency between sampling units, or recruiters and recruits that belong to the same social network. However, even with these limitations, we believe that the results reflect important aspects of individual, social, and programmatic vulnerability of MSM in the context of the HIV epidemic in the city of Salvador.

\section{Conclusion}

The findings in the analysis of vulnerability factors 10,11 among MSM that participated in the multicenter survey in Salvador 3,16 showed a situation of high individual, social, and programmatic vulnerability. In addition, the synergy between these factors can amplify their overall vulnerability 15 . Reports of exposure to discrimination and lack of formal employment, low schooling, and difficulty in accessing inputs and information for STI prevention are part of the reality and appear to mark the life histories 15 of these men ${ }^{16}$. These results corroborate findings from the literature in other populations of MSM, indicating that prevention and interventions are urgently needed to reduce these vulnerabilities and HIV infection and syphilis among MSM in Salvador.

\section{Resumen}

La vulnerabilidad social, individual y programática de los hombres que mantienen sexo con hombres (HSH) en un contexto de infección del VIH y enfermedades de transmisión sexual (ETS) es una realidad en muchos países. En la encuesta Comportamiento, Actitudes, Prácticas y Prevalencia de VIH y Sífilis entre Hombres que Practican Sexo con Hombres en 10 Ciudades Brasileñas, 383 hombres conformaron la selección en Salvador, Bahía, Brasil, según respondent driven sampling (RDS). El perfil de la vulnerabilidad personal es: inicio temprano de la actividad sexual (51\%), promedio de 8 parejas sexuales, la práctica de relaciones sexuales receptivas sin protección: pareja ocasional (32\%), fijos (45\%), VIH positivo (6,5\%) y sífilis (8,8\%). Vulnerabilidad social: adultos jóvenes (80\%), negros (91\%), con ingresos medios por hogar de R\$1.000,00 y que sufrieron algún tipo de discriminación (57\%). Factores programáticos: ninguna prueba de VIH en la vida (63\%) y sin acesso a gel lubrificante (88\%). Identificado un perfil de vulnerabilidad, y la urgente uimplementación de la intervención y la prevención de enfermedades de transmisión sexual entre los HSH en la ciudad. Hubo un perfil de vulnerabilidad y una necesidad urgente de acciones de intervención y prevención de enfermedades de transmisión sexual durante la investigación de la población en este municipio, además de una alta prevalencia de VIH y sífilis.

Homosexualidad Masculina; VIH; Sífilis;

Vulnerabilidad en Salud 


\section{Contributors}

S. Brignol participated in the data collection and analysis, interpretation of the results, literature review, and writing of the article. I. Dourado and L. D. Amorim collaborated in the data collection, interpretation of the results, and writing of the article. L. R. F. S. Kerr contributed to the study design, interpretation of the results, and writing of the article.

\section{Acknowledgments}

The authors wish to acknowledge the Department of STD/AIDS and VH of the Brazilian Ministry of Health, the Capes and CNPq research funding agencies, the coordinating body of the project Behavior, Attitudes, Practices, and Prevalence of HIV and Syphilis among Men Who Have Sex with Men in 10 Brazilian Cities, Grupo Gay da Bahia (GGB), the men who participated in the study, the Nucleus for Teaching and Research in AIDS and Other Infectious Diseases, the Institute of Collective Health, Federal University of Bahia (NEPADI/ISC/ UFBA), the scientific initiation scholarship students for their technical support, the team of interviewers, health professionals, and especially Rafaela Santos for her indispensable field supervision.

\section{References}

1. Beyrer C, Baral SD, van Griensven F, Goodreau SM, Chariyalertsak S, Wirtz AL, et al. Global epidemiology of HIV infection in men who have sex with men. Lancet 2012; 380:367-77.

2. Cáceres CF, Konda K, Segura ER, Lyerla R. Epidemiology of male same-sex behaviour and associated sexual health indicators in low- and middle-income countries: 2003-2007 estimates. Sex Transm Infect 2008; 84 Suppl 1:i49-56.

3. Kerr LR, Mota RS, Kendall C, Pinho AA, Mello MB, Guimarães MD, et al. HIV among MSM in a large middle-income country. AIDS 2012; 27:427-35.

4. Programa Nacional de DST, AIDS e Hepatites Virais, Secretaria de Vigilância em Saúde, Ministério da Saúde. Relatório de progresso da resposta brasileira ao HIV/AIDS (2010-2011)-UNGASS. Brasília: Ministério da Saúde; 2010.

5. Zou H, Fairley CK, Guy R, Bilardi J, Bradshaw CS, Garland SM, et al. Automated, computer generated reminders and increased detection of gonorrhoea, chlamydia and syphilis in men who have sex with men. PLoS One 2013; 8:e61972.

6. Pando MA, Balán IC, Marone R, Dolezal C, Leu CS, Squiquera L, et al. HIV and other sexually transmitted infections among men who have sex with men recruited by RDS in Buenos Aires, Argentina: high HIV and HPV infection. PLoS One 2012; 7:e39834.
7. Zoni AC, González MA, Sjögren HW. Syphilis in the most at-risk populations in Latin America and the Caribbean: a systematic review. Int J Infect Dis 2013; 17:e84-92.

8. Clark JL, Konda KA, Segura ER, Salvatierra HJ, Leon SR, Hall ER, et al. Risk factors for the spread of HIV and other sexually transmitted infections among men who have sex with men infected with HIV in Lima, Peru. Sex Transm Infect 2008; 84:449-54.

9. Chow EP, Wilson DP, Zhang L. HIV and syphilis co-infection increasing among men who have sex with men in China: a systematic review and metaanalysis. PLoS One 2011; 6:e22768.

10. Ayres JRCM, França Júnior I, Calazans GJ, Saletti Filho HC. O conceito de vulnerabilidade e as práticas de saúde: novas perspectivas e desafios. In: Czeresnia D, Freitas CM, organizadores. Promoção da saúde: conceitos, reflexões, tendências. Rio de Janeiro: Editora Fiocruz; 2009. p. 121-43.

11. Mann JM, Tarantola D. AIDS in the World II. Oxford: Oxford University Press; 1996.

12. Joint United Nations Programme on HIV/AIDS. Global report: UNAIDS report on the global AIDS epidemic. Geneva: World Health Organization; 2013. 
13. International AIDS Society. Declaração de Compromisso Washington D.C. Revertendo a maré em conjunto: uma declaração para acabar com a epidemia do HIV/SIDA. http://www.2endaids.org/ lang/portugese.html (accessed on 21/Dec/2012).

14. Gruskin S, Tarantola D. Universal access to HIV prevention, treatment and care: assessing the inclusion of human rights in international and national strategic plans. AIDS 2008; 22 Suppl 2: S123-32.

15. Delor F, Hubert M. Revisiting the concept of "vulnerability". Soc Sci Med 2000; 50:1557-70.

16. Brignol SMS. Estudo epidemiológico da infecção por HIV entre homens que fazem sexo com homens no município de Salvador [Tese de Doutorado]. Salvador: Instituto de Saúde Coletiva, Universidade Federal da Bahia; 2013.

17. Heckathorn DD. Respondent-driven sampling: a new approach to the study of hidden populations. Soc Probl 1997; 44:174-99.

18. Salganik MJ, Heckathorn DD. Sampling and estimation in hidden populations using respondent-driven sampling. Sociol Methodol 2004; 34: 193-240.

19. Magnani R, Sabin K, Saidel T, Heckathorn D. Review of sampling hard-to-reach and hidden populations for HIV surveillance. AIDS 2005;19 Suppl 2:S67-72.

20. Programa Nacional de DST, AIDS e Hepatites Virais, Secretaria de Vigilância em Saúde, Ministério da Saúde. Sífilis no Brasil. Brasília: Ministério da Saúde; 2003.

21. Programa Nacional de DST, AIDS e Hepatites Virais, Secretaria de Vigilância em Saúde, Ministério da Saúde. Prevalências e frequências relativas de doenças sexualmente transmissíveis (DST) em populações selecionadas de seis capitais brasileiras. Brasília: Ministério da Saúde; 2008.

22. Szwarcwald CL, Andrade CLT, Pascom ARP, Fazito E, Pereira GFM, Penha IT. HIV-related risky practices among Brazilian young men, 2007. Cad Saúde Pública 2011; 27 Suppl 1:S19-26.

23. Programa Nacional de DST, AIDS e Hepatites Virais, Secretaria de Vigilância em Saúde, Ministério da Saúde. Bela Vista e Horizonte: estudos comportamentais e epidemiológicos entre homens que fazem sexo com homens. Brasília: Ministério da Saúde; 2000.

24. Mimiaga MJ, Reisner SL, Bland S, Skeer M, Cranston $\mathrm{K}$, Isenberg D, et al. Health system and personal barriers resulting in decreased utilization of HIV and STD testing services among at-risk black men who have sex with men in Massachusetts. AIDS Patient Care STDS 2009; 23:825-35.

25. Dahoma M, Johnston LG, Holman A, Miller LA, Mussa M, Othman A, et al. HIV and related risk behavior among men who have sex with men in Zanzibar, Tanzania: results of a behavioral surveillance survey. AIDS Behav 2011; 15:186-92.

26. Price H, Gilson R, Mercey D, Copas A, Parry J, Nardone A, et al. Hepatitis $\mathrm{C}$ in men who have sex with men in London: a community survey. HIV Med 2013; 14:578-80.
27. Wheeler DP, Lauby JL, Liu KL, Van Sluytman LG, Murrill C. A comparative analysis of sexual risk characteristics of black men who have sex with men or with men and women. Arch Sex Behav 2008; 37:697-707.

28. Johnson CV, Mimiaga MJ, Reisner SL, Tetu AM, Cranston K, Bertrand T, et al. Health care access and sexually transmitted infection screening frequency among at-risk Massachusetts men who have sex with men. Am J Public Health 2009; 99 Suppl 1:S187-92.

29. Mizuno Y, Borkowf C, Millett GA, Bingham T, Ayala G, Stueve A. Homophobia and racism experienced by Latino men who have sex with men in the United States: correlates of exposure and associations with HIV risk behaviors. AIDS Behav 2012; 16: 724-35.

30. Deiss RG, Brouwer KC, Loza O, Lozada RM, Ramos $\mathrm{R}$, Cruz MAF, et al. High-risk sexual and drug using behaviors among male injection drug users who have sex with men in 2 Mexico-US border cities. Sex Transm Dis 2008; 35:243-9.

31. Mimiaga MJ, Goldhammer H, Belanoff C, Tetu AM, Mayer KH. Men who have sex with men: perceptions about sexual risk, HIV and sexually transmitted disease testing, and provider communication. Sex Transm Dis 2007; 34:113-9.

32. Instituto Brasileiro de Geografia e Estatística. Indicadores sociais municipais: uma análise dos resultados do universo do Censo Demográfico 2010. Rio de Janeiro: Instituto Brasileiro de Geografia e Estatística; 2011.

33. Programa Nacional de DST, AIDS e Hepatites Virais, Secretaria de Vigilância em Saúde, Ministério da Saúde. Pesquisa de conhecimentos, atitudes e práticas na população (PCAP) brasileira de 15 a 64 anos, 2008. Brasília: Ministério da Saúde; 2011.

34. Heilborn ML. Iniciação à sexualidade: métodos de socialização, interações de gênero e trajetórias individuais. In: Heilborn ML, Aquino EML, Bonzon M, Knauth DR, organizadores. O aprendizado da sexualidade: reprodução e trajetórias sociais de jovens brasileiros. Rio de Janeiro: Editora Garamond/Editora Fiocruz; 2006. p. 156-206.

35. Paiva V, Calazans G, Venturi G, Dias R. Idade e uso de preservativo na iniciação sexual de adolescentes brasileiros. Rev Saúde Pública 2008; 42 Suppl 1:45-53.

36. Heilborn ML, Cabral CS. As trajetórias homo-bissexuais. In: Heilborn ML, Aquino EML, Bonzon M, Knauth DR, organizadores. O aprendizado da sexualidade: reprodução e trajetórias sociais de jovens brasileiros. Rio de Janeiro: Editora Garamond/Editora Fiocruz; 2006. p. 361-97.

37. Baggaley RF, White RG, Boily MC. HIV transmission risk through anal intercourse: systematic review, meta-analysis and implications for HIV prevention. Int J Epidemiol 2010; 39:1048-63.

38. Beyrer C, Sullivan PS, Sanchez J, Dowdy D, Altman D, Trapence G, et al. A call to action for comprehensive HIV services for men who have sex with men. Lancet 2012; 380:424-38. 
39. Johnston L, O'Bra H, Chopra M, Mathews C, Townsend L, Sabin K, et al. The associations of voluntary counseling and testing acceptance and the perceived likelihood of being HIV-infected among men with multiple sex partners in a South African township. AIDS Behav 2010; 14:922-31.

40. Reisner SL, Mimiaga MJ, Bland S, Skeer M, Cranston K, Isenberg D, et al. Problematic alcohol use and HIV risk among black men who have sex with men in Massachusetts. AIDS Care 2010; 22:577-87.

41. Lauby JL, Millett GA, LaPollo AB, Bond L, Murrill CS, Marks G. Sexual risk behaviors of HIV-positive, HIV-negative, and serostatus-unknown Black men who have sex with men and women. Arch Sex Behav 2008; 37:708-19.

42. Berry M, Wirtz AL, Janayeva A, Ragoza V, Terlikbayeva A, Amirov B, et al. Risk factors for HIV and unprotected anal intercourse among men who have sex with men (MSM) in Almaty, Kazakhstan. PLoS One 2012; 7:e43071.

43. Baral S, Burrell E, Scheibe A, Brown B, Beyrer C, Bekker LG. HIV risk and associations of HIV infection among men who have sex with men in peri-urban Cape Town, South Africa. BMC Public Health 2011; 11:766.
44. Secretaria de Direitos Humanos, Presidência da República. Relatório sobre violência homofóbica no Brasil: ano de 2012. Brasília: Presidência da República; 2012.

45. Venturi G. Diversidade sexual e homofobia no Brasil. Intolerância e respeito às diferenças sexuais. São Paulo: Fundação Perseu Abramo; 2010.

46. Travassos C, Viacava F, Pinheiro R, Brito A. Utilização dos serviços de saúde no Brasil: gênero, características familiares e condição social. Rev Panam Salud Pública 2002; 11:365-73

47. Gomes R. Os homens cuidam pouco da saúde. Radis Comunicação e Saúde 2008; 74:10.

48. Terto Jr. V. Homossexualidade e saúde: desafios para a terceira década de epidemia de HIV/AIDS. Horizontes Antropológicos 2002; 8:147-58.

49. Malekinejad M, Johnston LG, Kendall C, Kerr LRFS, Rifkin MR, Rutherford GW. Using respondent-driven sampling methodology for HIV biological and behavioral surveillance in international settings: a systematic review. AIDS Behav 2008; 12:105-30.

50. White RG, Lansky A, Goel S, Wilson D, Hladik W, Hakim A, et al. Respondent driven samplingwhere we are and where should we be going? Sex Transm Infect 2012; 88:397-9.

Submitted on 15/Oct/2013

Final version resubmitted on 06/Jun/2014

Approved on 24/Sep/2014 